\title{
Serotonin Drives a Novel GABAergic Synaptic Current Recorded in Rat Cerebellar Purkinje Cells: A Lugaro Cell to Purkinje Cell Synapse
}

\author{
Isabel Dean, ${ }^{1 *}$ Susan J. Robertson, ${ }^{2 *}$ and Frances A. Edwards ${ }^{1}$ \\ ${ }^{1}$ Department of Physiology, University College London, London WC1E 6BT, United Kingdom, and ${ }^{2}$ Academic Department of Neurosurgery, Kings College \\ London, London SE5 9PJ, United Kingdom
}

\begin{abstract}
We recorded a novel fast GABAergic synaptic current in cerebellar Purkinje cells in rat brain slices using patch-clamp techniques. Because of a relatively low sensitivity to bicuculline, these currents can be recorded under conditions in which basket and stellate cell inputs are blocked. The observations that the novel synaptic currents occur spontaneously only in the presence of serotonin, and the specific limited positions in the slice from which they can be electrically evoked, suggest that the presynaptic cell is the Lugaro cell. Cell-attached recordings confirm that the Lugaro cell is the only interneuron in the cerebellar cortex with firing behavior consistent with the spontaneous activity recorded in Purkinje cells. The input shows a strong presynaptic modulation mediated by $\mathrm{GABA}_{\mathrm{A}}$ receptors, resulting in a dynamic range from almost 0 to $>90 \%$ release probability. Modeling $\mathrm{GABA}_{\mathrm{A}}$ receptor responses to different $\mathrm{GABA}$ transients suggests that the relatively low sensitivity of the synaptic currents to bicuculline, compared with the higher affinity $\mathrm{GABA}_{\mathrm{A}}$ receptor antagonist SR-95531 (2-(3-carboxypropyl)-3-amino-6-(4-methoxyphenyl) pyridazinium), is attributable to an unusually long GABA dwell time and/or high GABA concentration in the synaptic cleft. The significance of this novel input is discussed in relation to other GABAergic synapses impinging on Purkinje cells. We suggest that the release of GABA onto Purkinje cells from Lugaro cells would primarily occur during motor activity under conditions in which the activity of basket and stellate cells might be inhibited.
\end{abstract}

Key words: Purkinje cell; Lugaro cell; cerebellar cortex; IPSC; serotonin; $\mathrm{GABA}_{\mathrm{A}}$ receptor; kinetic model

\section{Introduction}

The axons of Purkinje cells collectively carry all of the output of the cerebellar cortex. Thus, the factors that determine the patterns of Purkinje cell firing are vital to the overall function of the cerebellum. Modeling studies indicate that, to produce the spontaneous irregular firing patterns that are the feature of their output in vivo, Purkinje cells must receive net synaptic inhibition over excitation (De Schutter, 1999; Jaeger and Bower, 1999). Indeed, single inhibitory inputs can dramatically alter Purkinje cellfiring rates and passive membrane properties in vitro (Häusser and Clark, 1997).

Powerful inhibitory control of Purkinje cells originates from interneurons of the cerebellar molecular layer, the basket and stellate cells (Eccles et al., 1966). These cells make numerous contacts with Purkinje cells, resulting in each Purkinje cell receiving a high level of synaptic inhibition. The Purkinje cell responses arising from the inputs of these common interneurons are readily identified and have been studied extensively. The postsynaptic currents are of particularly high amplitude and occur spontane-

Received Sept. 30, 2002; revised March 12, 2003; accepted March 14, 2003.

This work was supported by Wellcome Trust Grants 057997 and 054878 to I.D. and F.A.E. We acknowledge the important contributions of Dr. A. J. Gibb to the modeling, using software kindly provided by Prof. D. Colquhoun. We thank Profs. D. M. Kullmann and P. Jonas and Drs. S. G. Brickley, B. A. Clark, and C. H. Yeo for helpful comments on previous versions of this manuscript.

*I.D. and S.J.R. contributed equally to this work.

Correspondence should be addressed to Dr. Frances A. Edwards, Department of Physiology, University College London, Gower Street, London WC1E 6BT, UK. E-mail: f.a.edwards@ucl.ac.uk.

Copyright $\odot 2003$ Society for Neuroscience $\quad 0270-6474 / 03 / 234457-13 \$ 15.00 / 0$ ously at high frequency (Vincent and Marty, 1996; Häusser and Clark, 1997; Pouzat and Hestrin, 1997).

However, two other types of inhibitory neurons have axon collaterals projecting within the cerebellar cortex, about which little is known. The activity of both of these cell types, Lugaro cells (Sahin and Hockfield, 1990) and Purkinje cells (Chan-Palay, 1971), may add to the inhibitory system impinging onto Purkinje cells. The difficulty in studying the possibility of input from these neurons onto Purkinje cells is that their activity must be distinguished from the dominant activity of the basket and stellate cells. However, previous studies of Lugaro cells and their synapses on Golgi cells reveal features that may allow Lugaro cell inputs to Purkinje cells to be distinguished from those of other inhibitory interneurons (Dieudonné and Dumoulin, 2000).

The Lugaro cell is a rare type of neuron found in or just below the Purkinje cell layer (Aoki et al., 1986; Sahin and Hockfield, 1990). Little is known about the functional connections of Lugaro cells, except that there is evidence that they synapse with Golgi cells, and that these synapses release both GABA and glycine as synaptic cotransmitters (Dieudonné and Dumoulin, 2000; Dumoulin et al., 2001). The Lugaro cell has few, if any, fast excitatory synapses (Dieudonné, 2001) and is normally almost completely silent. Dieudonné and Dumoulin (2000) reported that bath-applied serotonin induces firing in the Lugaro cell, acting as one of the only known triggers that results in activity of this neuron.

Here we used these features of the Lugaro cell to investigate the possibility that they also synapse with Purkinje cells. We found a novel synaptic input to Purkinje cells, which we suggest 
originates from the Lugaro cell, and discuss the possible role of this novel inhibitory connection in the function of the cerebellum.

\section{Materials and Methods}

Preparation of slices. Sagittal cerebellar slices (400 $\mu \mathrm{m}$ thick) were prepared from 14-d-old Sprague Dawley rats using standard methods (Edwards et al., 1989). The cerebellum was cut along its midline through the vermis and glued on this surface for slicing. The slices were maintained in bubbled Krebs solution at $34^{\circ} \mathrm{C}$ for $20-30 \mathrm{~min}$. They were then transferred, within $30 \mathrm{~min}$ of slicing, to a second chamber containing fresh bubbled Krebs solution at $34^{\circ} \mathrm{C}$ before being cooled to room temperature. All recordings were made at room temperature $\left(21-24^{\circ} \mathrm{C}\right)$.

Solutions. The bath solution (Krebs) contained (in mM): $125 \mathrm{NaCl}, 2.4$ $\mathrm{KCl}, 2 \mathrm{CaCl}_{2}, 1 \mathrm{MgCl}_{2}, 26 \mathrm{NaHCO}_{3}, 1.1 \mathrm{NaH}_{2} \mathrm{PO}_{4}, 25$ glucose, and was bubbled with $95 \% \mathrm{O}_{2}-5 \% \mathrm{CO}_{2}$. In all experiments, 2,3-dioxo-6-nitro1,2,3,4-tetrahydro[f] quinoxaline-7-suphonamide (NBQX; $20 \mu \mathrm{M}$ ) and 7-chlorokynurenate $(10 \mu \mathrm{M})$ were also included in the bath solution to inhibit ionotropic glutamate receptors. The standard Krebs solution for recording the novel synaptic currents also contained $20 \mu \mathrm{M}$ bicuculline methochloride (referred to as bicuculline). For U-tube experiments, tetrodotoxin (TTX; $0.5 \mu \mathrm{M}$ ) was added to the bath solution. The solution in the U-tube contained (in $\mathrm{mM}$ ): $142 \mathrm{NaCl}, 2.4 \mathrm{KCl}, 2 \mathrm{CaCl}_{2}, 1 \mathrm{MgCl}_{2}, 25$ glucose, 10 HEPES, pH 7.4 with $\mathrm{NaOH}$, as well as $20 \mu \mathrm{M}$ NBQX, $10 \mu \mathrm{M}$ 7-chlorokynurenate, and $20 \mu \mathrm{M}$ bicuculline.

The standard intracellular solution contained (in $\mathrm{mm}$ ): $140 \mathrm{CsCl}, 5$ HEPES, 10 EGTA, $2 \mathrm{MgATP}$, and $2 \mathrm{CaCl}_{2}$, pH 7.4 with CsOH. We also used the following intracellular solutions containing (in $\mathrm{mM}$ ): 110 $\mathrm{N}$-methyl-D-glucamine (NMDG), $30 \mathrm{CsCl}, 10 \mathrm{EGTA}, 5 \mathrm{HEPES}, 2 \mathrm{CaCl}_{2}$, and $2 \mathrm{MgATP}, \mathrm{pH} 7.4$ with $\mathrm{HCl}$ (solution 1); 130 Cs gluconate, 10 $\mathrm{CsCl}, 10$ EGTA, 5 HEPES, $2 \mathrm{CaCl}_{2}$, and $2 \mathrm{MgATP}$, pH 7.4, with $\mathrm{CsOH}$ (solution 2).

$\mathrm{N}$-(2,6-dimethylphenylcarbamoylmethyl) triethylammonium bromide (QX-314), NBQX, bicuculline, and (1,2,5,6-tetrahydropyridine-4yl) methylphosphinic acid (TPMPA) were obtained from Tocris Cookson (Bristol, UK). Apamin was obtained from Alomone Labs (Jerusalem, Israel). 8,14-diaza-1,7(1,4)-diquinolinacyclotetradecaphane (UCL 1848) was a kind gift from Dr. Guy Moss (Department of Pharmacology, University College London, London, UK). The fluorescent dyes Alexa Red (Alexa Fluor 594) and Alexa Yellow (Alexa Fluor 488) were obtained from Molecular Probes (Eugene, OR). All other drugs were obtained from Sigma (Poole, UK). Bicuculline was made in distilled water freshly straight before the experiment. NBQX was dissolved in DMSO at $500 \times$ its final concentration. Aliquots of the concentrated NBQX were frozen at $-20^{\circ} \mathrm{C}$ and diluted into Krebs solution at the time of the experiment. 7-chlorokynurenate was dissolved in $\mathrm{NaOH}$ at $500 \times$ its final concentration ( $\mathrm{pH}$ adjusted to $~ 7.4$ ). All other drugs were dissolved in distilled water, and concentrated aliquots were similarly frozen.

Electrophysiology. Thick-walled borosilicate glass electrodes (World Precision Instruments, Hertfordshire, UK) were pulled to a tip resistance of 2-4 M $\Omega$ for recordings from Purkinje cells or $4-6 \mathrm{M} \Omega$ for recordings from Lugaro cells and molecular layer interneurons (PP-83 microelectrode puller; Narishige, Tokyo, Japan). The exact electrode resistance depended on the intracellular solution used. Cells were visually identified under infrared differential interference contrast microscopy, using a CCD camera (KP-M1E/K; Hitachi, Tokyo, Japan) mounted on an upright microscope (BX50WI; Olympus Optical, Tokyo, Japan). Wholecell voltage-clamp recordings were made from the somata of cells with an Axopatch 1-D patch-clamp amplifier (Axon Instruments, Foster City, CA), using standard methods (Edwards et al., 1989). The membrane potential was held at $-70 \mathrm{mV}$ (unless otherwise stated). Pipette series resistance was typically $10-20 \mathrm{M} \Omega$ and compensated by $60-80 \%$, as described previously (Llano et al., 1991). The quality of the recording was regularly checked by observing the current response to a $-10 \mathrm{mV}$ pulse, in the absence of the series resistance and capacitance compensations, and the recording was terminated if the shape or size of the response significantly altered. The NMDG Cl-based and CsCl-based intracellular solutions have negligible junction potentials (approximately -1 and 2
$\mathrm{mV}$, respectively). Data from experiments in which the Cs gluconatebased intracellular solution was used have been corrected for the $15 \mathrm{mV}$ junction potential.

Synaptic currents were evoked using minimal stimulation by applying bipolar rectangular voltage pulses of $100-200 \mu \mathrm{sec}$ duration at $0.5 \mathrm{~Hz}$ to a stimulating electrode (Grass SD9 stimulator; Astro-Med, West Warwick, RI). Stimulating electrodes were pulled in the same way as recording electrodes and filled with $1 \mathrm{~m} \mathrm{NaCl}$. The novel synaptic input was found by placing the tip of the stimulating electrode in the Purkinje cell layer and gradually increasing the stimulating voltage from zero until a synaptic current was observed that had an all-or-none relationship to stimulus strength. The stimulating electrode was then moved until the position was found at which the current could be evoked with the weakest stimulus. This was usually in the region of the fourth Purkinje cell soma around the folium from the cell being recorded. As mentioned above, the current was always found in the presence of $20 \mu \mathrm{m}$ bicuculline.

Currents were recorded from the amplifier at a bandwidth of $10 \mathrm{kHz}$ (four pole Bessel) and usually sampled on-line through a $2 \mathrm{kHz}$ filter (eight pole Bessell; Frequency Devices, Haverhill, MA) at a sampling frequency of $10 \mathrm{kHz}$ with an Axon Digidata 1200 (Axon Instruments) using the program WinWCP (kindly supplied by Dr. J. Dempster, University of Strathclyde, Glasgow, UK; available at www.strath.ac.uk/ Departments/PhysPharm/ses.htm).

U-tube. Fast applications of cis-4-aminocrotonic acid (CACA) and glycine to the slices were achieved with a solenoid valve-controlled U-tube system (Fenwick et al., 1982). At the start of each recording, a 500 msec pulse of control (HEPES) solution was applied, and the recording was discarded if the recorded cell showed any response. The agonists were then applied in three $500 \mathrm{msec}$ pulses, separated by at least $20 \mathrm{sec}$. Responses were averaged.

Imaging. Imaging of living cells was performed using an Olympus Fluoview confocal microscope (kindly supplied by Olympus Optical). Alexa Red or Alexa Yellow $(0.2 \mathrm{mg} / \mathrm{ml})$ were included in the CsCl-based intracellular solution for at least $10 \mathrm{~min}$ of whole-cell recording. The electrode was then removed before imaging. $Z$-series stacks were created from scans using a $20 \times$ or $40 \times$ water immersion objective.

Modeling. Synaptic currents were simulated by modeling the mean kinetics of single $\mathrm{GABA}_{\mathrm{A}}$ receptor channels with the program SCALCS (kindly provided by Professor D. Colquhoun, Department of Pharmacology, University College London, London, UK; available at http://www. ucl.ac.uk/Pharmacology/dc.html). A Q-matrix algorithm (Colquhoun and Hawkes, 1995) was used to find the occupancy as a function of time of each state in the seven-state model shown below.

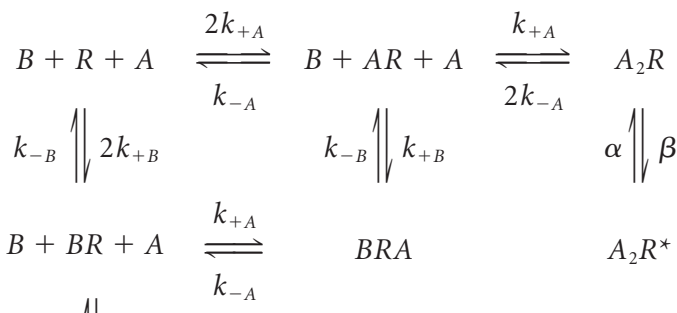

$$
\begin{aligned}
& 2 k_{-B} \| k_{+B} \\
& B_{2} R
\end{aligned}
$$

Terms in the model are as follows: $R, \mathrm{GABA}_{\mathrm{A}}$ receptor; $A, \mathrm{GABA} B$, antagonist; $R^{\star}$, open state; $k_{+A}$ or $k_{+B}$, association rate of GABA or antagonist with $\mathrm{GABA}_{\mathrm{A}}$ receptor; $k_{-A}$ or $k_{-B}$, dissociation rate of GABA or antagonist from $\mathrm{GABA}_{\mathrm{A}}$ receptor; $\beta, \mathrm{GABA}_{\mathrm{A}}$ receptor channelopening rate; $\alpha, \mathrm{GABA}_{\mathrm{A}}$ receptor channel closing rate.

The following rate constants were used: (on rates, $\mathrm{M}^{-1} \mathrm{sec}^{-1}$ ) GABA, $5 \times 10^{6}$; bicuculline, $5 \times 10^{7} ; 2$-(3-carboxypropyl)-3-amino-6-(4methoxyphenyl) pyridazinium (SR-95531), $1.8 \times 10^{7}$; (off rates, sec $^{-1}$ ) GABA, 131; bicuculline, 62; SR-95531, 6; channel closing rate, 400; channel opening rate, 2000 . The rate constants of the antagonists were taken from Jones et al. (2001); other rates were taken from Jones et al. (1998), apart from the channel-opening rate, which was taken from the data of Maconochie et al. (1994) for Purkinje cell $\mathrm{GABA}_{\mathrm{A}}$ receptors. 
In the model, single-channel traces (duration, 5-100 msec) were generated in response to concentration jumps of GABA in which the GABA concentration had an exponential rise (time constant, $0.1 \mathrm{msec}$ ) and an exponential decay as described in Results. The initial GABA concentration was modeled as zero. In simulations of the effects of antagonists, the antagonist was present at a fixed concentration before and throughout the GABA concentration jump. Traces of average current were analyzed from ASCII files, by reading off the peak current and the $10-90 \%$ rise time of the current.

Analysis. All recordings were analyzed using WinWCP (as described above). To obtain average peak amplitudes of evoked synaptic currents, at least 50 consecutive currents were averaged, including any failures. The latencies of evoked synaptic currents were measured from the start of the stimulus artifact to the start of the synaptic response, as judged by eye. Current decay times were measured by fitting a single exponential curve to the average current. For analysis of spontaneous synaptic currents, the program WinCDR (kindly supplied by Dr. J. Dempster, University of Strathclyde) was used to detect spontaneous events, using the following detection criteria: to be classified as a spontaneous current, an event had to cross an amplitude threshold of $5 \mathrm{pA}$ for $5 \mathrm{msec}$, with a dead time between consecutive events of $15 \mathrm{msec}$. This gives an effective detection threshold of $\sim 8-12 \mathrm{pA}$. Note that in Figure $2 C$, the minimum event amplitude was well above this detection threshold. Detected events were then inspected by eye to avoid inclusion of artifacts. Data are presented as means \pm SEM, apart from data that were not normally distributed, and are therefore presented as medians. Results were analyzed as indicated (see Results), using the Prism statistics package (Graph Pad, San Diego, CA). Results were considered significant if the probability of chance occurrence was $<0.05$.

\section{Results}

We investigated the possibility that, similarly to their inputs to Golgi cells (Dumoulin et al., 2001), Lugaro cells might release glycine as well as GABA at synapses onto Purkinje cells. Detection of glycinergic currents is possible under conditions in which the known inhibitory synaptic currents in Purkinje cells, arising from basket and stellate cells, are blocked.

In the presence of antagonists of ionotropic glutamate receptors (20 $\mu \mathrm{M}$ NBQX and $10 \mu \mathrm{M} 7$-chlorokynurenate), all Purkinje cells displayed a high level of spontaneous synaptic activity, as described previously (Vincent and Marty, 1996; Häusser and Clark, 1997). In agreement with previous studies, almost all of this spontaneous activity was fully blocked by $20 \mu \mathrm{M}$ bicuculline (Fig. 1), identifying the synaptic currents as being carried by $\mathrm{GABA}_{\mathrm{A}}$ receptors. The effect of bicuculline was fully reversible (Fig. $1 B$ ). All subsequent experiments, unless otherwise stated, were performed in the presence of $20 \mu \mathrm{M}$ NBQX and $10 \mu \mathrm{M}$ 7-chlorokynurenate, in which glutamatergic synaptic currents from climbing fibers and parallel fibers were inhibited, and $20 \mu \mathrm{M}$ bicuculline, in which GABAergic synaptic currents from basket and stellate cells were inhibited. This will be referred to as the "standard bath solution."

From previous reports of Lugaro cell activity (Dieudonné and Dumoulin, 2000), it was predicted that if Lugaro cells make synaptic contact with Purkinje cells, such synapses would be silent in the standard bath solution but would be active if serotonin were added to the bath. Similarly, if the Lugaro cell axon were stimulated directly, by current applied from an extracellular stimulating electrode placed in the region in which Lugaro cells are found, synaptic currents would be evoked in Purkinje cells.

\section{Bath application of serotonin induced spontaneous synaptic activity} In 18 of 22 Purkinje cells, no synaptic currents were detected in the standard bath solution, and in the remaining four cells, the
$\mathbf{A}$

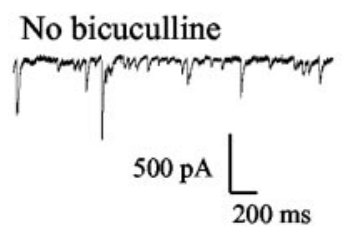

$20 \mu \mathrm{M}$ bicuculline

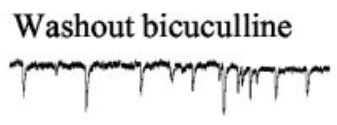

B

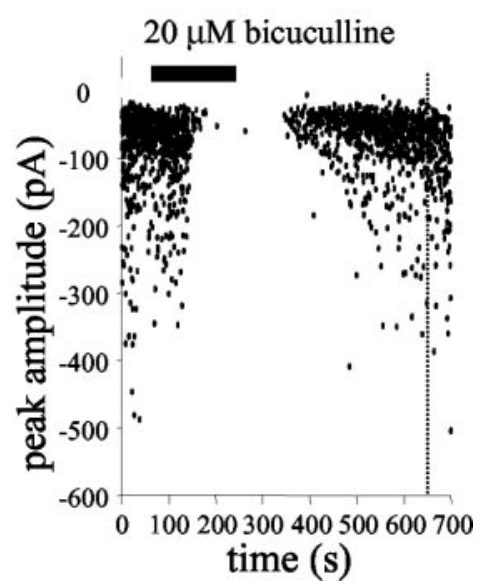

Figure 1. All spontaneous synaptic activity in most Purkinje cells was inhibited in the standard bath solution. Data were recorded in $20 \mu \mathrm{M} \mathrm{NBQX}$ and $10 \mu \mathrm{m}$ 7-chlorokynurenate throughout. $A$, Three seconds of whole-cell voltage-clamp recording from a cerebellar Purkinje cell before (top trace) and during (middle trace) the addition to the bath of $20 \mu \mathrm{m}$ bicuculline and after washout of bicuculline (bottom trace). GABAergic synaptic currents were inward because of the high chloride content of the intracellular solution. Scale bars apply to all traces. $B$, Time course of the effect on current amplitude of wash-in and washout of bicuculline. Points on the graph represent the peak amplitude of individual currents. The dotted line represents a full washout of bicuculline when mean amplitude returned to the control value.
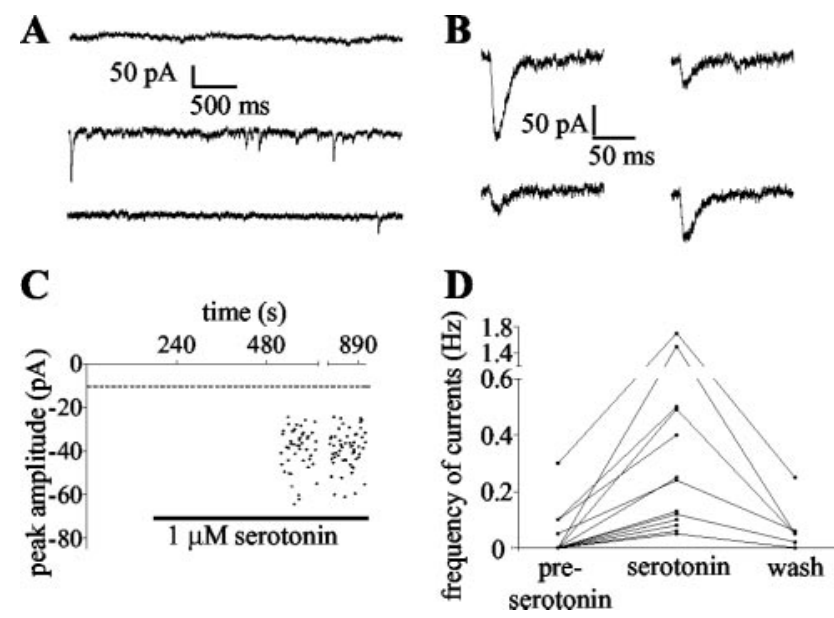

Figure 2. Serotonin evoked spontaneous synaptic currents in the standard bath solution. $A$, Whole-cell voltage-clamp recording from a cerebellar Purkinje cell in the standard bath solution

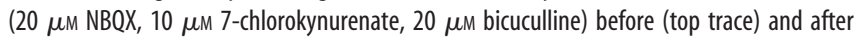
(middle trace) the addition to the bath of serotonin $(1 \mu \mathrm{m})$ and after washout of serotonin (bottom trace). $B$, Individual serotonin-induced synaptic currents are shown on a slower time base. C, Time course of appearance of spontaneous currents after application of serotonin. Points represent the peak amplitude of individual currents. Note the all-or-nothing appearance of currents at full amplitude. The dotted line represents the approximate detection threshold. The break in the axis was a period during which the holding potential was varied. $D$, Data from individual cells illustrating the effect of serotonin on the frequencies of spontaneous synaptic currents.

synaptic activity was very infrequent, occurring at frequencies between 0.05 and $0.3 \mathrm{~Hz}$. Bath application of $1 \mu \mathrm{M}$ serotonin caused a marked increase in the spontaneous synaptic activity recorded in Purkinje cells (Fig. 2). This effect of serotonin was observed in 13 of 22 (59\%) Purkinje cells tested. In the remaining nine cells, no synaptic currents were detected before or during application of serotonin. Across the 13 cells in which synaptic activity increased in serotonin, the median frequency of synaptic 
currents occurring before the application of serotonin was $0 \mathrm{~Hz}$ (25-75\% quartiles; $0-0.08 \mathrm{~Hz} ; n=13)$. During the application of $1 \mu \mathrm{M}$ serotonin, the median frequency increased to $0.24 \mathrm{~Hz}(0.1-0.5 \mathrm{~Hz}$; $n=13)$. This result was highly statistically significant, even including the cells that remained silent $(n=22 ; p<0.001$; Wilcoxon matched-pairs signed rank sum test). The amplitudes and kinetics of the spontaneous synaptic currents recorded in the presence of serotonin are detailed in Table 1.

The effect of serotonin was reversible (Fig. 2D). When serotonin was washed from the bath, the median frequencies of synaptic currents returned toward control levels $(0.05 \mathrm{~Hz} ; n=6)$. The appearance of serotonin-dependent synaptic currents was compatible with the hypothesis that the synaptic inputs were from Lugaro cells impinging onto Purkinje cells, because Lugaro cells are the only interneurons in the cerebellar cortex reported to be normally silent but consistently increase their firing rates in response to serotonin (Dieudonné and Dumoulin, 2000).

\section{Similar synaptic currents could be evoked by electrical stimulation, but only in the vicinity of Lugaro cells}

Having established that serotonin-induced currents could be recorded in the presence of bicuculline, we attempted to evoke these synaptic currents electrically. Note that with post hoc morphological analysis, using fluorescent dyes, Lugaro cells can be identified in the slice. However, they are sparsely distributed (Sahin and Hockfield, 1990; Lainé and Axelrad, 1996) and rarely visible from the surface, making it highly unlikely that synaptically connected cell pairs could be successfully patched. However, the position of Lugaro cells in the cerebellar slice is well established (Aoki et al., 1986; Sahin and Hockfield, 1990; Lainé and Axelrad, 1996), and hence we attempted to evoke synaptic currents by stimulating extracellularly in the region in which Lugaro cell axons would be expected to run. We again used the standard bath solution, in which inputs to Purkinje cells from climbing fibers, parallel fibers, basket cells, and stellate cells were blocked. By placing the tip of a stimulating electrode on the surface of the cerebellar slice within the Purkinje cell layer, in the region of approximately the fourth Purkinje cell along the folium from the recorded cell, synaptic currents were consistently evoked (Fig. $3 A, B$ ) (see Materials and Methods for details). The currents were characteristically all-or-nothing in nature, appearing suddenly above threshold at a certain amplitude. The amplitude of the currents remained constant as the stimulating voltage was increased further (Fig. 3C). This suggested that the evoked currents were caused by the activation of a single axon or possibly a few axons that ran very closely together. In some cases, to investigate the location of the presynaptic cell after evoking currents in this initial position, the stimulating electrode was moved in an attempt to track the path of the presynaptic axon. In all cases $(n=$ 8 ), the currents could only be evoked by stimulating in a band $\sim 30-40 \mu \mathrm{m}$ wide running along the Purkinje cell layer in one direction only from the recorded cell. In four of eight cases, this band stretched for at least $400 \mu \mathrm{m}$, with the farthest stimulating position being $\sim 800 \mu \mathrm{m}$ around the folium from the recorded cell. Under these conditions, the currents recorded were similar to those evoked with the stimulation electrode placed in the initial stimulating position. Currents could never be evoked by placing the electrode in the cerebellar white matter, where Purkinje cell axons would be expected to run, and rarely when the tip of the

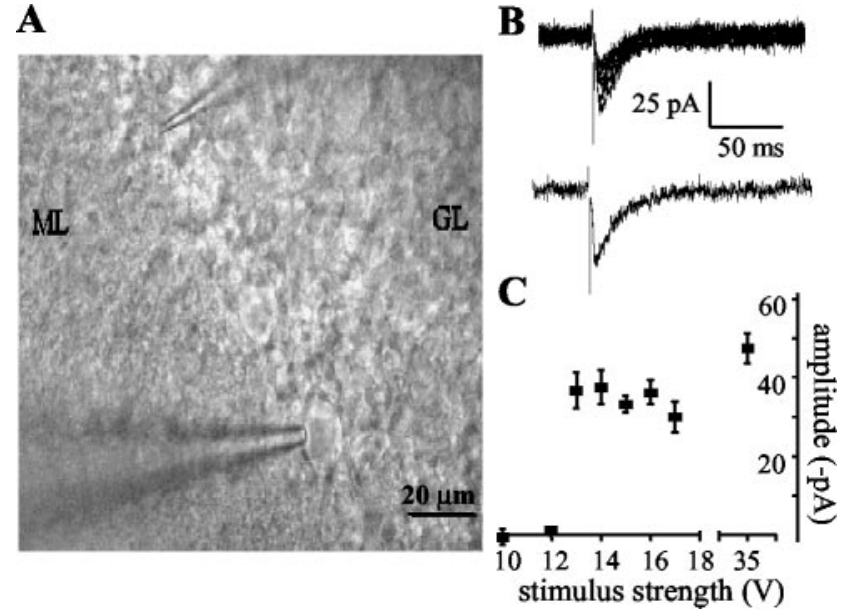

Figure 3. Synaptic currents were evoked in the standard bath solution using minimal stimulation in the Purkinje cell layer. $A$, Micrograph of typical positions of electrodes for recording the evoked synaptic currents. The recording electrode (bottom) is patched onto a Purkinje cell, and the tip of the stimulating electrode (top) is placed in the Purkinje cell layer in the region between Purkinje cells, approximately three to four Purkinje cell somata along the folium from the recorded cell. ML, Molecular layer; GL, granule cell layer. B, Typical recordings of evoked synaptic currents in the standard bath solution ( $20 \mu \mathrm{M} \mathrm{NBQX}, 10 \mu \mathrm{m}$ 7-chlorokynurenate, and $20 \mu \mathrm{m}$ bicuculline). The top panel shows six consecutive individual traces. The bottom panel shows an individual trace from the same cell. C, The evoked synaptic currents appeared at full amplitude as the stimulus was increased above threshold ( $13 \mathrm{~V}$ in this cell). With stimulating voltages substantially higher than threshold, only $\sim 10 \mathrm{pA}$ additional current was evoked. Each point is the mean amplitude \pm SEM of 10 consecutive traces from one cell.

stimulating electrode was placed on the cell bodies of other Purkinje cells. Currents could never be evoked in the standard bath solution when the tip of the stimulating electrode was placed farther from the Purkinje cell band in the molecular layer, where basket and stellate cells are most commonly found.

The evoked currents were sensitive to the extracellular calcium concentration. They were completely blocked when the $\mathrm{Na}^{+}$channel antagonist TTX $(1 \mu \mathrm{M})$ was added to the bath but were not affected by inclusion of the $\mathrm{Na}^{+}$channel antagonist QX-314 (10 mM) in the intracellular solution, and therefore were not attributable to direct activation of the recorded Purkinje cell (data not shown). Thus, the currents behaved typically for postsynaptic currents evoked by the stimulation of an action potential in a presynaptic cell. The successful stimulating positions were compatible with stimulation of the axons of Lugaro cells.

The properties of the evoked currents and the serotonininduced spontaneous currents were then compared. Both the amplitudes and kinetics (rise times and decay times) of the two groups of currents were very similar, showing no significant difference (Table 1), which is consistent with the currents arising from the same source. 

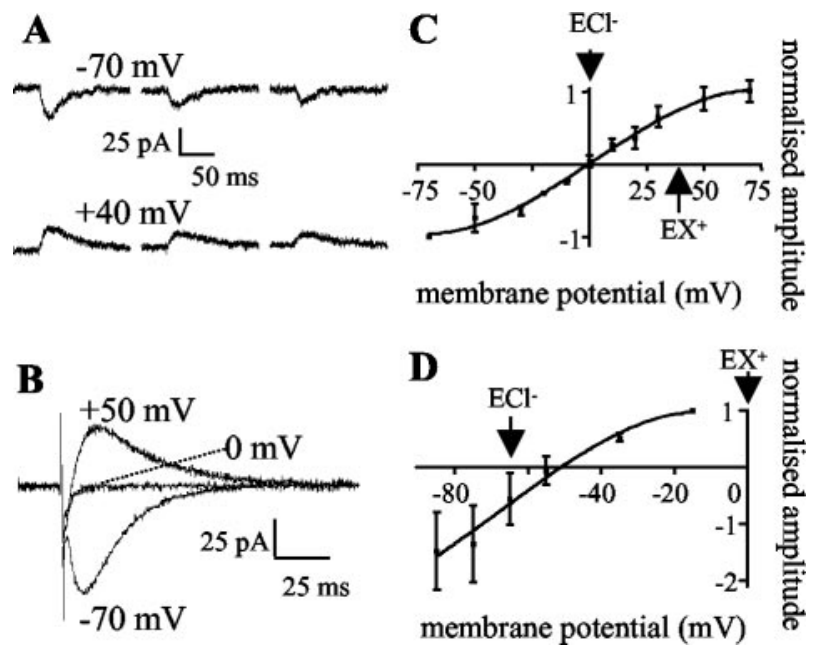

Figure 4. The novel synaptic currents were carried by anions. $A$, Three consecutive serotonin-induced synaptic currents recorded using the NMDG CI-based intracellular solution at the holding potentials indicated. $B$, Averaged evoked synaptic currents recorded using the NMDG Cl-based intracellular solution at the holding potentials indicated. C, D, The currentvoltage relationship of the evoked currents reversed near the predicted reversal potential for chloride ions $\left(\mathrm{ECl}^{-}\right)$. C, NMDG Cl-based intracellular solution. $\mathrm{ECl}^{-}, 2 \mathrm{mV}$; predicted reversal potential for cations $\left(\mathrm{EX}^{+}\right), 40 \mathrm{mV}$; observed reversal potential, $-0.25 \mathrm{mV}$. D, Cs gluconatebased intracellular solution. $\mathrm{ECl}^{-},-66 \mathrm{mV} ; \mathrm{EX}^{+}, 3 \mathrm{mV}$; observed reversal potential, $-51 \mathrm{mV}$. Points are mean current amplitudes \pm SEM from at least three cells. Amplitudes are normalized to those at $-70 \mathrm{mV}(C)$ or $-15 \mathrm{mV}(D)$.

The novel synaptic currents were carried by $\mathrm{Cl}^{-}$ions

Transmission at Lugaro cell synapses onto Golgi cells is mediated by corelease of GABA and glycine (Dumoulin et al., 2001); the postsynaptic responses to Lugaro cell input would therefore be predicted to be carried by anions. Under conditions of symmetrical $\mathrm{Cl}^{-}$ion concentrations (NMDG Cl-based intracellular solution; solution 1; see Materials and Methods), the serotonininduced synaptic currents recorded from Purkinje cells reversed at $\sim 0 \mathrm{mV}$, and hence were carried by anions (Fig. $4 A$ ). The ion permeability of the evoked synaptic currents could be investigated in more detail. Using the NMDG Cl-based intracellular solution, the evoked synaptic currents also reversed at $\sim 0 \mathrm{mV}$ (Fig. $4 B$ ). When the $\mathrm{Cl}^{-}$concentration gradient was changed, using a Cs gluconate-based intracellular solution (solution 2; see Materials and Methods), the evoked currents again reversed near to the predicted reversal potential for $\mathrm{Cl}^{-}$(Fig. 4C). Thus, both the evoked currents and the serotonin-induced currents were carried by anions.

The synaptic currents were mediated by $\mathrm{GABA}_{\mathrm{A}}$ receptors with lower than expected sensitivity to bicuculline

In view of the resistance of the currents to the $\mathrm{GABA}_{\mathrm{A}}$ receptor antagonist bicuculline and previous reports of release by Lugaro cells of glycine as well as GABA (Dumoulin et al., 2001), glycine was the most likely candidate for a neurotransmitter at the novel synapse. However, the glycine receptor antagonist strychnine (5 $\mu \mathrm{M})$, when added to the standard bath solution, did not affect the amplitude of the serotonin-induced currents (103 $\pm 2.5 \%$ compared with standard bath solution; $n=4$ ) or that of the evoked currents ( $94 \pm 0.04 \%$ compared with standard bath solution; $n=$ 4) (Fig. 5A). Furthermore, to investigate the possibility that, in postnatal rats 2 weeks of age, glycine receptors were still in the relatively strychnine-insensitive neonatal form (Kuhse et al., 1990), we tested for any response to glycine (10 mM) in Purkinje cells in the presence of strychnine $(5 \mu \mathrm{M})$, using a U-tube appli-
A

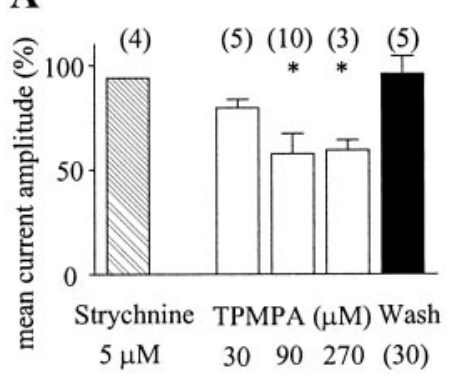

C

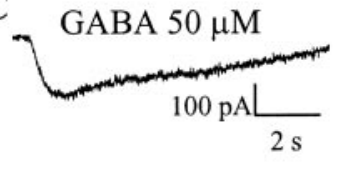

Glycine $10 \mathrm{mM}$

CACA $200 \mu \mathrm{M}$

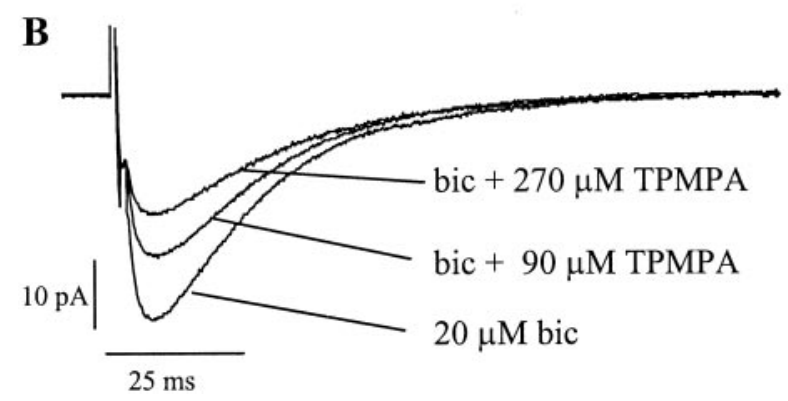

Figure 5. The novel synaptic currents were not mediated by glycine receptors or by $\mathrm{GABA}_{\mathrm{C}}$ receptors. $A$, Bath application of the glycine receptor antagonist strychnine did not affect the amplitudes of the evoked synaptic currents. The GABA ${ }_{C}$ receptor antagonist TPMPA caused some concentration-dependent reduction in evoked current amplitude, but the inhibition was less than that expected for $\mathrm{GABA}_{C}$ receptor-mediated responses. Data from all cells, normalized to amplitudes in the standard bath solution, are shown. Values are means \pm SEM (the error bar on the strychnine data is too small to be visible). ${ }^{*} p<0.05$; one-way ANOVA. Numbers in parentheses indicate the numbers of cells tested. $B$, Averaged evoked currents from one cell showing the effect of bath-applied TPMPA. bic, Bicuculline. C, Averaged responses of Purkinje cells to U-tube application of receptor agonists. Top, GABA $(50 \mu \mathrm{m})$; middle, glycine $(10 \mathrm{~mm})$ in the presence of strychnine $(5 \mu \mathrm{m})$; bottom, CACA $(200 \mu \mathrm{M})$. All responses were recorded in the presence of $20 \mu \mathrm{M} \mathrm{NBQX}, 10 \mu \mathrm{m}$ 7-chlorokynurenate, $20 \mu \mathrm{m}$ bicuculline, and $0.5 \mu \mathrm{m}$ TTX. Calibration applies to all traces.

cation system. No response was seen $(n=7)$ (Fig. $5 C)$. In contrast, U-tube application of GABA always evoked a response (Fig. $5 C$ ), confirming that the applied solution was reaching the cells.

Purkinje cells express all three subunits of the bicucullineinsensitive $\mathrm{GABA}_{\mathrm{C}}$ receptor (Boué-Grabot et al., 1998; Rozzo et al., 2002). The $\mathrm{GABA}_{\mathrm{C}}$ receptor antagonist TPMPA caused a dose-dependent decrease in the amplitude of the evoked synaptic currents (Fig. $5 A, B$ ). However, the inhibition caused by TPMPA was not compatible with a major involvement of $\mathrm{GABA}_{\mathrm{C}}$ receptors, but rather appeared to reflect a nonspecific effect of the drug. The dissociation equilibrium constant $\left(K_{\mathrm{B}}\right)$ of TPMPA at $\mathrm{GABA}_{\mathrm{C}}$ receptors is 2-16 $\mu \mathrm{M}$ (Ragozzino et al., 1996; Chebib et al., 1998), whereas the amplitude of the currents in $270 \mu \mathrm{M}$ TPMPA was still $59.5 \pm 5 \%(n=3)$ of control. Moreover, the $K_{\mathrm{B}}$ of TPMPA at $\mathrm{GABA}_{\mathrm{A}}$ receptors is $320 \mu \mathrm{M}$ (Ragozzino et al., 1996), so a partial inhibition of the currents by $270 \mu \mathrm{M}$ could even reflect an effect on $\mathrm{GABA}_{\mathrm{A}}$ receptors. We also found no Purkinje cell response to the $\mathrm{GABA}_{\mathrm{C}}$ receptor agonist CACA $(200 \mu \mathrm{M})$, applied with the U-tube in the presence of bicuculline $(20 \mu \mathrm{M}$; $n=10$ ) (Fig. $5 C$ ). Thus, it is unlikely that the synaptic currents are carried by $\mathrm{GABA}_{\mathrm{C}}$ receptors.

Having discounted glycine receptors and $\mathrm{GABA}_{\mathrm{C}}$ receptors, we investigated the possible role of $\mathrm{GABA}_{\mathrm{A}}$ receptors. The concentration of bicuculline in which the synaptic currents were normally evoked $(20 \mu \mathrm{M})$ is at least 40 -fold higher than the predicted $\mathrm{IC}_{50}$ of bicuculline for inhibiting $\mathrm{GABA}_{\mathrm{A}}$ receptor- 
mediated synaptic currents (Schneggenburger and Konnerth, 1992; Jonas et al., 1998) and would therefore be expected to inhibit such currents fully. Indeed, as noted above, in most cases, no detectable spontaneous synaptic activity remained in Purkinje cells from basket cell or stellate cell inputs in this recording solution. However, increasing the concentration of bicuculline to even higher levels (up to 100 $\mu \mathrm{M}$ ) caused a dose-dependent inhibition of the evoked synaptic currents (Fig. 6A).

We therefore investigated the effect on the synaptic currents of another $\mathrm{GABA}_{\mathrm{A}}$ receptor antagonist, SR-95531, which has an approximately threefold higher affinity for $\mathrm{GABA}_{\mathrm{A}}$ receptors than that of bicuculline (Seutin et al., 1997; Ueno et al., 1997; Hamann et al., 1988; Jones et al., 2001). We substituted bicuculline $(20 \mu \mathrm{M})$ with a threefold lower concentration of SR$95531(6 \mu \mathrm{M})$, predicting that currents mediated by $\mathrm{GABA}_{\mathrm{A}}$ receptors should remain at approximately the same amplitude with this substitution of antagonists. We washed the SR-95531 solution into the bath for at least $7 \mathrm{~min}$ and in most cases for $>12 \mathrm{~min}$ before analyzing the effect of the substitution, because we established previously, in experiments examining inputs to Purkinje cells from basket and stellate cells, that $7 \mathrm{~min}$ was the time needed to achieve full washout of bicuculline (Fig. $1 B$ ). However, rather than being equivalent in its potency, $6 \mu \mathrm{MSR}-95531$ inhibited the evoked synaptic currents to $<20 \%$ of their amplitude in $20 \mu \mathrm{M}$ bicuculline (12 of 14 cells). Even $3 \mu \mathrm{M}$ SR-95531 caused an almost $50 \%$ inhibition of currents initially recorded in the standard bath solution (Fig. 6B,C). The effect of SR-95531 was reversible on washing back into bicuculline. Thus, the receptors underlying the evoked synaptic currents are inhibited by $\mathrm{GABA}_{\mathrm{A}}$ receptor antagonists but display a pharmacology that is not typical of that previously reported for GABAergic synaptic currents.

Similarly to the evoked currents, the serotonin-induced spontaneous currents showed an unusual pharmacology: they were completely inhibited when SR-95531 (6 $\mu \mathrm{M})$ was substituted for bicuculline $(20 \mu \mathrm{M})$. This effect was reversible on washing back into bicuculline. Note that the $>80 \%$ reduction in amplitude observed in the experiments on the evoked currents would result in all except the largest serotonin-induced currents falling below the detection threshold.

\section{Release of GABA at the novel synaptic input was strongly} presynaptically modulated in a bicuculline-sensitive manner Having found that the synaptic currents were mediated by $\mathrm{GABA}_{\mathrm{A}}$ receptors, it was of interest to observe the currents in the absence of bicuculline. We therefore evoked the synaptic currents using our usual methods and then washed bicuculline out of the bath. This procedure was necessary, because starting experiments in the absence of bicuculline would have prevented us from distinguishing the novel current from currents arising from the common basket cell or stellate cell inputs. Moreover, this experiment could only be performed on the evoked currents, because the synaptic currents from basket and stellate cells made it impossible to distinguish the randomly occurring serotonininduced currents in the absence of bicuculline.

As bicuculline was removed, the evoked synaptic currents increased in amplitude, further indicating that they are carried by
$\mathbf{A}$
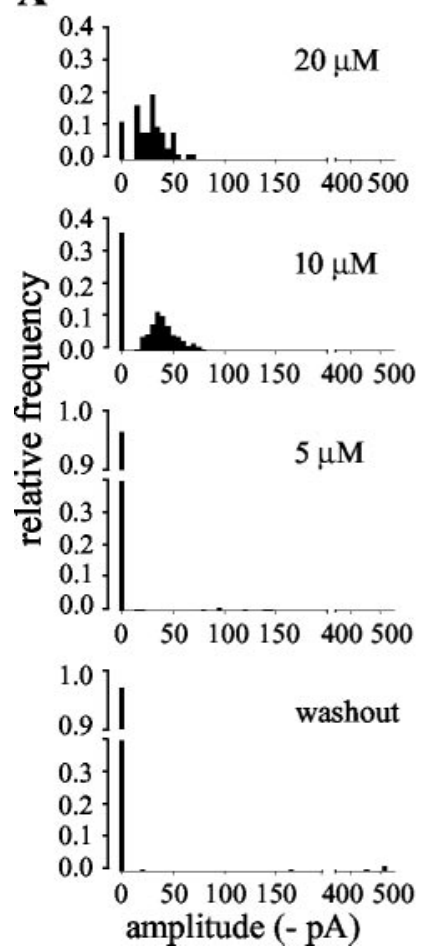

B

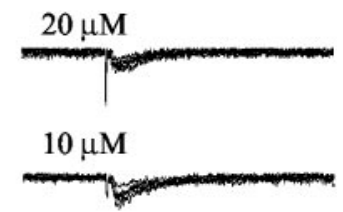

$5 \mu \mathrm{M}$

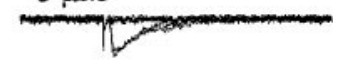

washout

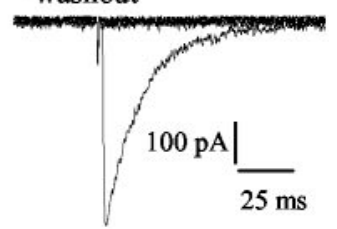

C

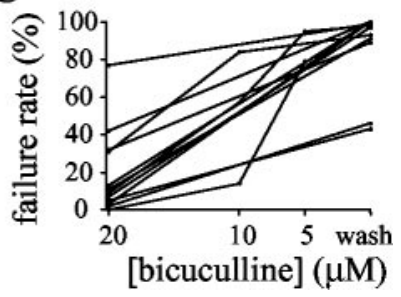

Figure 7. The novel synaptic inputs displayed bicuculline-sensitive presynaptic inhibition. A, Histograms of amplitudes of evoked currents recorded from one cell during washout of bicuculline. For clarity, failures have been plotted at $0 \mathrm{pA}$. Note the breaks in the axes. As the bicuculline concentration was reduced, the amplitudes of the evoked currents increased, but the failure rate also increased. $B$, Six consecutive raw traces of evoked currents from the same cell as $A$ at each concentration of bicuculline (indicated above each trace). Calibration applies to all traces. C, Consistent effect of washout of bicuculline on the failure rates of the synaptic currents in all cells tested.

$\mathrm{GABA}_{\mathrm{A}}$ receptors. In the absence of bicuculline, the currents remaining were very large (up to $>1 \mathrm{nA}$ in some cells). However, the increase in amplitude was accompanied by a dramatic increase in failure rate, such that in the absence of bicuculline, the stimulus very rarely caused the presynaptic cell to release transmitter (Fig. 7). Thus, under these conditions, the remaining currents were presumably caused by release from a single presynaptic site. 
In each case, the stimulation threshold was regularly checked during washout of bicuculline. In many cases, the threshold decreased during washout, because currents arising from inputs that were previously inhibited appeared above the noise level. If the threshold changed, the cell was discarded; this ensured that the current arose through stimulation of the same input cell alone throughout the experiment. However, note that if extra inputs began to contribute to the currents recorded as bicuculline was removed from the solution, the predicted result would be a decrease in the failure rate, and hence such an error would only lead to an underestimate of the phenomenon observed.

The median failure rates of the evoked synaptic currents in 20 $\mu \mathrm{M}$ bicuculline and after the removal of bicuculline were $10 \%$ (25-75\% quartiles, $4-32 \%)$ and $97 \%$ (90-100\%), respectively $(p<0.005$; Wilcoxon matched-pairs signed rank sum test; $n=$ 11). In some experiments $(n=3)$, the bicuculline was washed out in stages and the increase in failure rate was then seen to be dose-dependent, as shown in Figure 7C.

In two out of four cells, partial transient recovery of the synaptic release was seen on replacing bicuculline.

In each experiment, spontaneous synaptic currents in the Purkinje cells appeared as bicuculline was removed from the bath solution. Thus, as the novel synapse was failing to release and the currents were becoming increasingly unreliable, the common GABAergic inputs to the cells (presumably arising from basket and stellate cells) were becoming unblocked and regaining their activity.

The presynaptic effects of bicuculline were mediated by $\mathrm{GABA}_{\mathrm{A}}$ receptors and not by small conductance calciumactivated potassium channels

The quaternary salts of bicuculline used in our experiments inhibit not only $\mathrm{GABA}_{\mathrm{A}}$ receptors but also small conductance calcium-activated potassium channels (SK channels) (Seutin et al., 1997; Khawaled et al., 1999; Strøbæk et al., 2000). In contrast, SR-95531 does not affect SK channels (Seutin et al., 1997; Seutin and Johnson, 1999). The results described above show that bicuculline exerts a relatively weak postsynaptic effect on the novel synaptic currents, compared with SR-95531, and a strong presynaptic effect. One hypothesis that could explain both of these observations is that the input features presynaptic SK channels, which inhibit the release of GABA. In this case, release would be inhibited because bicuculline was washed out of the slice, whereas with increasing bicuculline concentration, presynaptic release would increase, causing an apparent decrease in the postsynaptic inhibition of the currents. If the unexpected difference in the potencies of bicuculline and SR-95531 was partially caused by inhibition of SK channels, then an antagonist of SK channels should reduce inhibition of the currents by SR-95531. We therefore tested the SK channel antagonists apamin (33 nM) and UCL $1848(100 \mathrm{nM})$ in the presence of SR-95531 (6 $\mu \mathrm{M})$ (Chen et al., 2000; Shah and Haylett, 2000). Neither SK channel antagonist had any effect on the amplitude of the currents (mean amplitude in $6 \mu \mathrm{M}$ SR-95531 plus SK channel antagonist was $96 \pm 13.7 \%$ of amplitude in SR-95531 alone; $n=8$ ). Thus, the difference in effects of the two $\mathrm{GABA}_{\mathrm{A}}$ receptor antagonists was not attributable to inhibition of SK channels by bicuculline.

Additionally, we tested the effects of a benzodiazepine on the novel synaptic currents. In our standard bath solution (including $20 \mu \mathrm{M}$ bicuculline), flurazepam $(1 \mu \mathrm{M})$ caused an increase in the amplitudes (137.9 $\pm 6.3 \%$ in flurazepam; $p<0.005$; Student's paired $t$ test; $n=8)$ and decay times (138.0 $\pm 6.4 \%$ in flurazepam; $p<0.0005$; Student's paired $t$ test; $n=8$ ) (Fig. $8 A$ ) of the evoked
$\mathbf{A}$

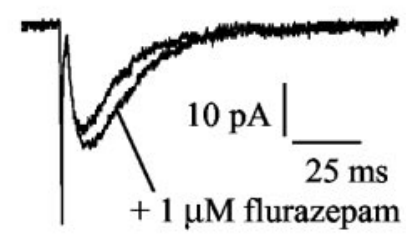

B
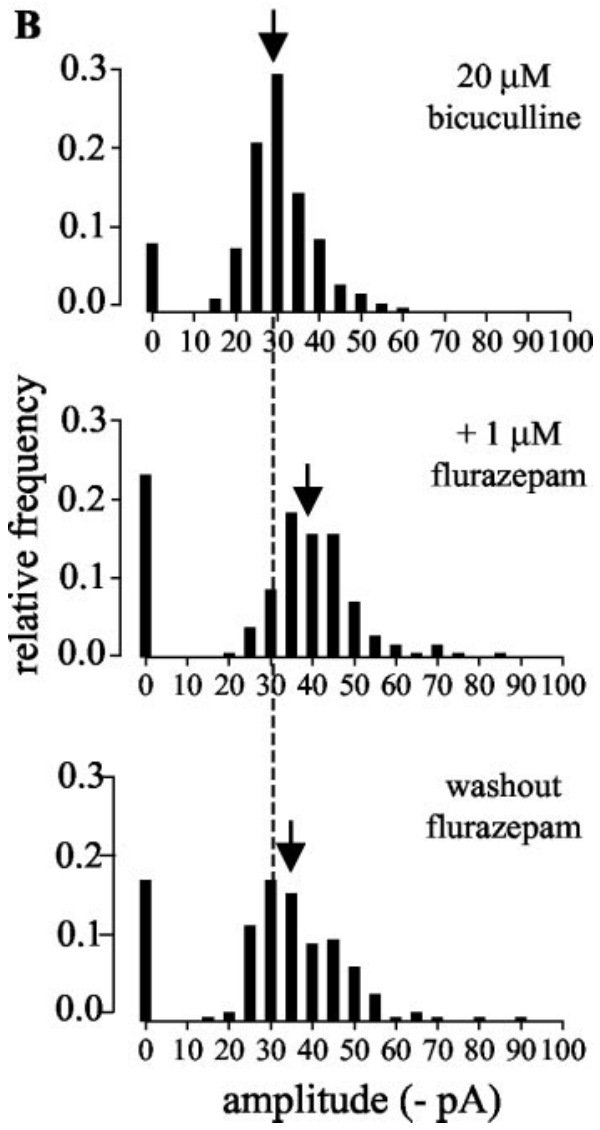

Figure 8. The effects of flurazepam confirm that the presynaptic inhibition of the novel synaptic inputs was mediated by $G A B A_{A}$ receptors. $A$, Effect of flurazepam on the amplitude and decay times of the evoked currents. Averaged currents (excluding failures) from one cell in the standard bath solution before and after the addition of flurazepam are shown. $B$, Histograms of amplitudes of evoked currents recorded in the standard bath solution ( $20 \mu \mathrm{m}$ bicuculline), showing the effect of flurazepam on current amplitudes and failure rates. Failures have been plotted at 0 pA. Similarly to the effect of the washout of bicuculline, bath application of flurazepam caused an increase in both the failure rates and the amplitudes of the evoked synaptic currents. The dashed line indicates the median current amplitude in the standard bath solution before application of flurazepam; the arrows indicate the median current amplitude under each condition.

synaptic currents. These effects are typical of a synaptic current mediated by $\mathrm{GABA}_{\mathrm{A}}$ receptors and are additional evidence that the currents were not carried by $\mathrm{GABA}_{C}$ receptors, which are insensitive to benzodiazepines (Shimada et al., 1992; Wang et al., 1994; Shingai et al., 1996). Flurazepam also caused a decrease in presynaptic release probability. The median failure rates of the evoked currents in the absence and presence of $1 \mu \mathrm{M}$ flurazepam were 12 and $32 \%$, respectively $(p<0.05$; Wilcoxon matchedpairs signed rank sum test; $n=6$ ) (Fig. $8 B$ ). This effect on failure rates reversed, after removing flurazepam, in two of four cells.

The sensitivity of the presynaptic modulation of release to both bicuculline and benzodiazepine, together with the lack of effect of SK channel antagonists, indicate that the presynaptic 
inhibition is mediated via $\mathrm{GABA}_{\mathrm{A}}$ receptors. We tested whether bicuculline exerts presynaptic effects on the commonly encountered GABAergic inputs by evoking currents in the absence of bicuculline using minimal stimulation in the molecular layer, where basket and stellate cells are found. The mean amplitude of the currents evoked was $256 \pm 46 \mathrm{pA}(n=17)$, close to the mean amplitudes reported previously (Pouzat and Hestrin, 1997; Than and Szabo, 2002). We found that bicuculline $(2 \mu \mathrm{M})$ had no effect on the failure rates of these currents (mean failure rates in bicuculline; $112 \pm 25 \%$ of control; $n=10$ ), suggesting that, as reported previously (Saitow et al., 2000), $\mathrm{GABA}_{\mathrm{A}}$ receptors do not modulate release probability at the common GABAergic inputs to Purkinje cells. Because $2 \mu \mathrm{M}$ bicuculline substantially inhibited the currents arising from the basket/stellate cell inputs (to $32.6 \pm$ $5.1 \%$ of control amplitude), this was the highest concentration of bicuculline in which the currents could still be detected at sufficient amplitude to count failures.

\section{Kinetic modeling suggests that bicuculline sensitivity could be decreased by an unusual profile of transmitter concentration in the synaptic cleft}

One possible explanation for the relative insensitivity of the novel GABAergic synaptic currents to bicuculline compared with SR95531 is that the postsynaptic receptors themselves are atypical, such that previously reported affinities of these antagonists do not apply. Such a receptor could, for example, constitute a heteromultimer of $\mathrm{GABA}_{\mathrm{A}}$ and $\mathrm{GABA}_{\mathrm{C}}$ receptor subunits.

Another possibility is that the profile of the GABA concentration at the synapse has unusual features, so that comparing the binding affinities of different antagonists does not give a good prediction of their relative potencies. The dissociation equilibrium constant $\left(K_{\mathrm{B}}\right)$ of an antagonist approximates the concentration that will result in a $50 \%$ block of the available binding sites in the absence of agonist. In central synapses mediated by ionotropic receptors, the transmitter is thought to be present in the synaptic cleft at high concentrations $(\sim 0.5-3 \mathrm{~mm}$ peak concentration) (Maconochie et al., 1994; Jones and Westbrook, 1995; Cherubini and Conti, 2001) for only a very brief period (halftime of the transmitter transient $<1 \mathrm{msec}$ (Clements, 1996; Cherubini and Conti, 2001). Modeling of transmitter dwell times in GABAergic synapses at room temperature from synaptic data has resulted in estimates of transmitter decay time constants of 50-100 $\mu$ sec (Mozrzymas et al., 1999). With such brief exposure to the transmitter, the transmitter and the antagonist do not come into equilibrium, and the amplitude of the postsynaptic response depends only on the number of receptors that are unoccupied by the antagonist at the time of the transmitter arriving at the postsynaptic membrane. Thus, using a two binding site model of a receptor in which only one antagonist molecule needs to bind to prevent activation, $75 \%$ of receptors will be inhibited at the $K_{\mathrm{B}}$ of the antagonist. [It can be calculated that at the concentrations of antagonists used in this study (bicuculline, $20 \mu \mathrm{M}$; SR-95531, $6 \mu \mathrm{M}), \sim 99.6 \%$ of receptors would be inhibited.] However, as the dwell time of the transmitter in the synaptic cleft is increased, the transmitter and the antagonist will gradually come into equilibrium. This will decrease the potency of a competitive antagonist in a manner dependent on the relative affinity of the antagonist and the transmitter concentration profile (Clements et al., 1992). Thus, considering the different affinities of bicuculline and SR-95531, we have modeled the effects on a synaptic current of changing GABA dwell time and concentration in the presence of each antagonist. The parameters used for the model and their sources are detailed in Materials and Meth-

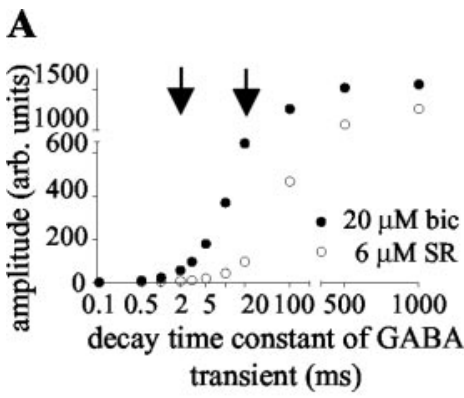

C

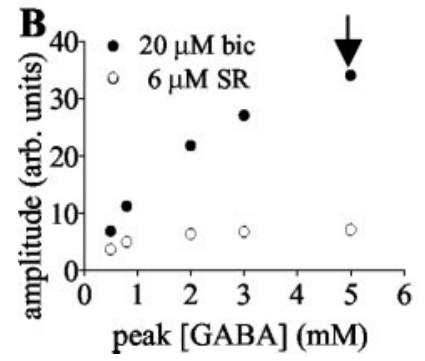

Experimental data

Figure 9. Models of competitive antagonism of $\mathrm{GABA}_{A}$ receptors show that increasing the duration of the GABA transient or the peak GABA concentration reduces the potency of competitive antagonists. The potency of bicuculline (bic) is affected to a greater extent than that of SR-95531 (SR). A, Model A, Peak GABA concentration, $0.8 \mathrm{~mm}$. With brief GABA transients (decay time constant, $<0.5 \mathrm{msec}$ ), the antagonists are approximately equipotent at the "matched" concentrations (20 $\mu \mathrm{m}$ bicuculline, $6 \mu \mathrm{m}$ SR-95531). As the decay time constant of the GABA transient is increased, the amplitude of the residual current in bicuculline increases more rapidly than that in SR-95531. At two positions along the dwell time axis ( 2 and $20 \mathrm{msec}$ ), the ratio of the current amplitudes in the two antagonists is similar to that seen experimentally (arrows). $B$, Model $B$ shows the effect of increasing the peak concentration of GABA (decay time constant of GABA transient, $0.5 \mathrm{msec})$. The arrow indicates the concentration at which the ratio of current amplitudes in the two antagonists is similar to that seen experimentally. C, Effect of bicuculline on current rise times. Left, Modeled currents (model A shown) have slower rise times in the presence of bicuculline $(20 \mu \mathrm{m})$. Right, Experimental data indicating that washout of bicuculline caused a decrease in the rise time of the evoked synaptic currents. Averaged evoked currents are shown from one cell. Currents in bicuculline are scaled to the amplitude of those in the absence of bicuculline.

ods and were taken from a consensus of different published studies (Maconochie et al., 1994; Jones et al., 1998, 2001).

The results of the modeling indicate that if the GABA transient is modeled with values approximating those reported for fast synapses (peak GABA concentration, $0.8 \mathrm{~mm}$; decay time constant of GABA transient, $0.1 \mathrm{msec}$ ), the effects of bicuculline (20 $\mu \mathrm{M})$ and SR-95531 $(6 \mu \mathrm{M})$ on a synaptic current would be similar. However, increasing either the dwell time of GABA (model A) or the peak GABA concentration (model B) decreases the potency of competitive antagonists. The potency of the lower affinity antagonist bicuculline is affected to a greater extent than that of SR95531 (Fig. 9).

For model A, using a peak GABA concentration of $0.8 \mathrm{~mm}$, the relative potencies of bicuculline and SR-95531 in the model match the experimental data if the transmitter decay time constant is raised to $\sim 2 \mathrm{msec}$. With longer dwell times, the potencies diverged further but reconverge to a similar ratio at $\sim 20 \mathrm{msec}$ (Fig. 9A).

For model B, using a decay time constant of $0.5 \mathrm{msec}$ for the GABA transient, the relative potencies of bicuculline and SR95531 in the model also match the experimental data if the peak concentration of GABA is raised to $\sim 5 \mathrm{~mm}$ (Fig. $9 B$ ).

The first solution of model A $(2 \mathrm{msec})$ predicts a rise time of the synaptic current of $4.5 \mathrm{msec}$, which is consistent with the relatively slow rise time of the experimentally recorded synaptic 
currents in bicuculline (Table 1). However, the second solution of model A (20 msec) gives too slow a current rise time (19.6 $\mathrm{msec}$ ). Model B could also be consistent with the experimental data, predicting a current rise time of $2.1 \mathrm{msec}$. An additional prediction of the modeling is that the rise times of the synaptic currents should become faster as bicuculline is removed. We have therefore investigated this experimentally. As predicted, removal of bicuculline caused the rise times of the evoked synaptic currents to decrease in all cells (by $41.1 \pm 10 \% ; n=6$ ) (Fig. 9C). The modeling predicts a decrease in rise time on removal of bicuculline of 70\% (model A) and 60\% (model B). In contrast, SR-95531 would be expected to have considerably less effect than bicuculline on the rise time. Indeed, substituting $20 \mu \mathrm{M}$ bicuculline with $6 \mu \mathrm{M}$ SR-95531 resulted in a decrease in rise time of $34.2 \pm 3.1 \%$ $(n=5)$, resulting in rise times similar to values after washout of bicuculline.

Rise time data can be difficult to interpret, because they are sensitive to other factors, such as dendritic filtering. In particular, removing bicuculline might decrease the input resistance of the Purkinje cell, which would also be predicted to lead to a decrease in rise time. However, when bicuculline was replaced with SR95531, the input resistance would not be expected to decrease and, as noted, the rise times also became faster under these conditions.

Thus, it is not necessary to propose the involvement in this synapse of a novel GABA receptor. The apparent discrepancies in potency of bicuculline and SR-95531 can be explained by a dwell time and/or peak concentration of GABA in the synaptic cleft that is sufficient to allow dissociation of bicuculline from its binding site on the $\mathrm{GABA}_{\mathrm{A}}$ receptor. Note that the exact values for our estimates of GABA concentration and dwell time depend on the kinetic model of the $\mathrm{GABA}_{\mathrm{A}}$ receptor used. However, we have tested a wide range of rate constants for the model and also included a monoliganded open state and obtained qualitatively similar results both for relative efficacy of the antagonists at different GABA concentrations and dwell times and for the changes in rise time of the currents.

Lugaro cells are the only neurons in cerebellar slices that were initially inactive and consistently increased their firing rate in response to bath application of serotonin

We have described a synaptic current carried by $\mathrm{GABA}_{\mathrm{A}}$ receptors that arises from an input to Purkinje cells that is normally silent but is activated to release transmitter if (1) serotonin is added to the bath or (2) cells are extracellularly stimulated within a band running along the Purkinje cell layer. These observations are qualitatively compatible with the behavior and position of Lugaro cells. However, Purkinje cells, basket cells, and stellate cells, which are GABAergic, all form synapses with Purkinje cells. In order for any of these cell types to be the presynaptic cell underlying the novel synaptic currents, they would have to release transmitter rarely or not at all onto Purkinje cells under control conditions.

We used cell-attached recordings in the standard bath solution to measure action potential frequency in these cell types. Purkinje cells fired at high frequencies under control conditions (in the standard bath solution) $(13 \pm 2.3 \mathrm{~Hz} ; n=7)$. Similarly, when basket and stellate cells in the inner and outer molecular layer were recorded in the standard bath solution, they also fired at high frequencies $(5.4 \pm 1.1 \mathrm{~Hz} ; n=4)$. These results are in agreement with previous reports (Than and Szabo, 2002). In recordings in which the novel currents were evoked using extracellular stimulation, the input showed a reliability of release of $\sim 90 \%$ in the standard bath solution. Therefore, the very low frequency of spontaneous synaptic activity in Purkinje cells in this solution suggests that the novel input is unlikely to arise from a presynaptic Purkinje cell, basket cell, or stellate cell.

Therefore, it seems that the Lugaro cell is indeed the most likely candidate for the presynaptic cell underlying the novel synaptic currents. However, Dieudonné and Dumoulin (2000) reported that serotonin increased Lugaro cell firing rates to a steady frequency of $5-15 \mathrm{~Hz}$, which is considerably higher than the frequencies of synaptic currents reported here $(0.1-0.5 \mathrm{~Hz})$. The difference in frequencies may be attributable to the different experimental conditions of the two studies. We have therefore examined the behavior of Lugaro cells under the present conditions, using cell-attached recordings to investigate the effect of serotonin on Lugaro cell firing rates. We recorded from cells with large elongated somata, lying in or just below the Purkinje cell layer. However, the identification of Lugaro cells under differential contrast optics is difficult and therefore, where possible, after having obtained a cell-attached recording, the recording was taken into whole-cell mode. The solution in the recording electrode contained a fluorescent dye that filled the cell, allowing morphological identification.

The cells recorded fell into three groups. Thirty-three cells never fired before or during the application of serotonin and showed no synaptic activity. On morphological inspection, they were identified as Bergmann glia or other types of glial cells (Fig. $10 \mathrm{~A})$. These cells showed characteristically low input resistances $(63 \pm 8 \mathrm{M} \Omega ; n=6)$.

Four other cells fired at high frequency before serotonin was added to the bath $(3.4 \pm 1.5 \mathrm{~Hz} ; n=4)$ and were thus incompatible with the presynaptic cells generating the serotonin-induced currents. After application of serotonin, these cells showed varied behavior, increasing $(n=1)$, decreasing $(n=2)$, or not changing their firing rates $(n=1)$. Three of these cells were filled and identified as basket cells or Golgi cells (Fig. 10B).

The final group of eight cells (Fig. 10C,D) showed firing patterns that were compatible with the serotonin-induced currents. Six of these eight cells were silent before exposure to serotonin (up to 9 min of control recording), and the other two cells fired irregularly and rarely (each at $0.05 \mathrm{~Hz}$ ). In all cases, bath application of serotonin $(1 \mu \mathrm{M})$ resulted in a marked increase in the firing rates of these cells (median firing rate in serotonin, $0.5 \mathrm{~Hz}$; 25-75\% quartiles; $0.4-1.2 \mathrm{~Hz}$; median delay to onset of firing, $190 \mathrm{sec})$. This increase in firing rates was highly statistically significant $(p<0.01$; Wilcoxon matched-pairs signed rank sum test; $n=8$ ). Four of these eight cells were successfully filled and studied morphologically (Fig. 10C). All four cells were identified as Lugaro cells according to three criteria based on previous publications of Lugaro cell morphology (Lainé et al., 1992; Dieudonné, 2001): (1) the somata lay at the top border of the granule cell layer beneath the Purkinje cell layer, (2) the somata were elliptical in shape and emitted large-diameter processes from both poles in the sagittal plane, and (3) these processes were primarily confined throughout their course to the border between the granule cell layer and the Purkinje cell layer. These last two criteria are unique to Lugaro cells and differentiate them from other cell types that can lie in similar positions in the cerebellar slice. Moreover, in contrast to the glia, which were the only other initially silent cells, the input resistance was high (995 \pm $263 \mathrm{M} \Omega ; n=4)$.

Thus, under the conditions of the experiments in this study, Lugaro cells behaved similarly to the previous report by Dieudonné and Dumoulin (2000), in that they were nearly silent in the 

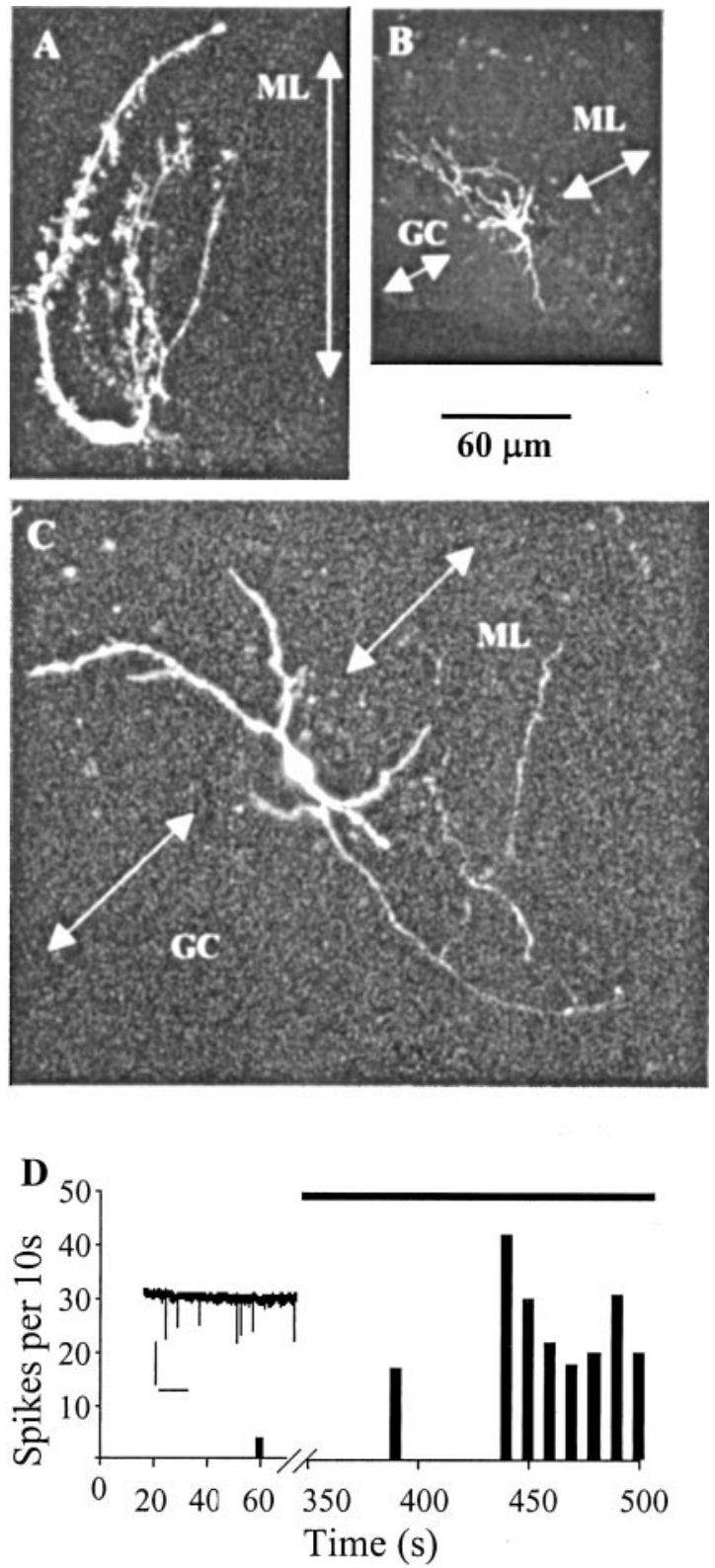

Figure 10. The firing activity of Lugaro cells mimicked the pattern of serotonin-induced synaptic currents recorded from Purkinje cells. $A-C$, Confocal images of three cells recorded in cell-attached mode for firing activity and then filled in whole-cell mode with Alexa Fluor 594. $\mathrm{ML}$, Molecular layer; $\mathrm{GC}$, granule cell layer. The arrows are at right angles to the line of the Purkinje cell layer. A, Bergmann glial cell. $B$, Basket cell. $C$, Lugaro cell. The four main processes of the cell follow the line of the Purkinje cell layer. $D$, Firing rate of the cell shown in C from a cell-attached recording performed in $20 \mu \mathrm{M} N \mathrm{NQX}, 10 \mu \mathrm{m}$ 7-chlorokynurenate, and $20 \mu \mathrm{m}$ bicuculline. Spikes were counted in 10 sec bins. The cell fired four times in 80 sec before exposure to serotonin; bath application of $1 \mu \mathrm{m}$ serotonin (indicated by black bar) caused the cell to fire irregularly at an average frequency of $\sim 2 \mathrm{~Hz}$. Note the break in the $x$-axis. Inset, Seven action currents recorded over $10 \mathrm{sec}$ after $\sim 7 \mathrm{~min}$ in serotonin. Calibration: $40 \mathrm{pA}, 2 \mathrm{sec}$.

absence of serotonin but increased their firing rates when serotonin was added to the bath. The serotonin-induced firing rates measured here were lower than in this previous report but were not significantly different from the frequencies of serotonininduced synaptic currents recorded in Purkinje cells (MannWhitney test; $p>0.05$ ). Thus, both studies are internally consistent with the firing rates being similar to the rate of synaptic activity recorded postsynaptically. The difference between the results of the two studies presumably reflects the differences in experimental conditions, including the strain of rat, the presence of GABA and glutamate receptor antagonists, and the region of the cerebellum used.

Therefore, in this study, the Lugaro cell is the only cell type that shows initial low activity and is induced to fire by serotonin in a manner compatible with the presynaptic cell mediating the serotonin-induced currents recorded from Purkinje cells.

\section{Discussion}

We describe a novel GABAergic synaptic current recorded in Purkinje cells. All of the features of the synaptic currents are compatible with input from Lugaro cells, and indeed, this is the only type of neuron present in the cerebellar slice with firing patterns compatible with the novel synaptic activity. The synaptic input shows an unusual postsynaptic sensitivity to competitive $\mathrm{GABA}_{\mathrm{A}}$ receptor antagonists and is under strong presynaptic control via $\mathrm{GABA}_{\mathrm{A}}$ receptors.

\section{The presynaptic source of the novel synaptic current}

The novel synaptic currents occur only in the presence of serotonin or on extracellular stimulation. The serotonin-induced currents appeared in an all-or-nothing manner, as did the evoked currents on increasing stimulus voltage. This behavior of the novel currents strongly suggests that serotonin or extracellular stimulation caused release of the transmitter from previously silent synapses onto Purkinje cells. Lugaro cells are the only normally silent neurons in the cerebellar cortex and the only neurons that are consistently induced to fire by serotonin. These properties already strongly suggest that Lugaro cells are the presynaptic neurons mediating the novel synaptic currents. The fact that the currents can only be evoked by stimulating within a limited band around the Purkinje cell layer, in the region in which Lugaro cell somata and dendrites lie and their axons would be expected to run, also strengthens this conclusion. These evoked currents share not only the same amplitude and kinetics but also the unusual pharmacology of the serotonin-induced currents, and therefore most likely originate from the same source.

The other candidate GABAergic neurons that are known to impinge on Purkinje cells are other Purkinje cells, basket cells, and stellate cells. However, the high convergence of all of these inputs onto Purkinje cells (Bernard and Axelrad, 1993; Häusser and Clark, 1997), their high spontaneous firing frequency under control conditions, and the high probability of transmitter release at the novel input would predict a high frequency of spontaneous synaptic currents in the absence of serotonin. The near absence of such spontaneous synaptic currents therefore renders these cells unlikely candidates for the presynaptic cell type.

Thus, the results suggest that Lugaro cells form synapses onto Purkinje cells. The data allow certain conclusions to be drawn regarding the connectivity of these inputs. Under our standard conditions, postsynaptic currents occurred in response to almost every extracellular stimulus. Branch point failures in Lugaro cell axons are unlikely to be common, because the release probability remained high even when stimulating far from the recorded Purkinje cell. When the firing rates of Lugaro cells were recorded and compared with the frequencies of the synaptic currents in Purkinje cells, there was no significant difference. Together, these observations suggest that only one Lugaro cell contributes to the synaptic activity recorded in each Purkinje cell. Despite the scarcity of Lugaro cells compared with Purkinje cells (Sahin and Hockfield, 1990; Lainé and Axelrad, 1996; Dieudonné and Dumoulin, 2000), serotonin evoked synaptic currents in more than half of the recorded Purkinje cells. Therefore, each Lugaro 
cell must send inputs to many Purkinje cells. The absence of an effect of serotonin on the synaptic activity in 9 of 22 Purkinje cells is consistent with the activation of serotonin receptors near the soma of a presynaptic cell, causing the cell to fire. In this case, the effect of serotonin would only occur if the presynaptic soma were preserved within the slice. Because the recorded Purkinje cells were located close to the surface of the slice, the probability of a presynaptic Lugaro cell soma lying below the Purkinje cell within the slice rather than being severed in slicing would be $\sim 0.5$. The proportion of Purkinje cells in which serotonin evoked synaptic currents $(\sim 0.5)$ therefore suggests that every Purkinje cell would receive Lugaro cell input in the intact cerebellum. The lack of effect of serotonin on the synaptic activity of some Purkinje cells is also evidence that the currents did not arise from basket or stellate cells, which connect in high numbers onto all Purkinje cells, as noted above.

\section{Pharmacology of the novel currents}

Unlike the Lugaro cell input to Golgi cells, which shows a glycinergic component (Dumoulin et al., 2001), the input to Purkinje cells is mediated by only $\mathrm{GABA}_{\mathrm{A}}$ receptors, as demonstrated by the effects of the high-affinity $\mathrm{GABA}_{\mathrm{A}}$ receptor antagonist SR95531, the benzodiazepine flurazepam, and high concentrations of bicuculline. Nevertheless, the currents can be recorded in bicuculline concentrations in which all other GABAergic inputs to Purkinje cells are blocked.

In contrast to most neurons, Purkinje cells express relatively few $\mathrm{GABA}_{\mathrm{A}}$ receptor subunits (Fritschy et al., 1992; Laurie et al., 1992). The $\mathrm{GABA}_{\mathrm{A}}$ receptor antagonists bicuculline and SR95531 display an approximately threefold difference in potency at most $\mathrm{GABA}_{\mathrm{A}}$ receptors, including all of those present in Purkinje cells (Hamann et al., 1988; Lüddens and Korpi, 1995; Seutin et al., 1997; Ueno et al., 1997; Jones et al., 2001). Thus, perhaps a more likely explanation than a novel GABA receptor for the relative insensitivity of the currents to bicuculline is that suggested by our modeling study. A simple model in which GABA remains in the synaptic cleft for several milliseconds and/or is released at very high concentrations describes not only the relative potencies of the two antagonists but also the slow bicuculline-dependent rise time of the currents. Such a GABA concentration profile may be compatible with an unusual synaptic morphology, which prevented fast clearance of transmitter by diffusion. Perhaps more likely is the possibility that, under our experimental conditions, multiple vesicles are released. Such multivesicular release has been reported to occur at glutamatergic synapses and indeed causes a decrease in the potency of low-affinity competitive antagonists (Tong and Jahr, 1994; Wadiche and Jahr, 2001). Furthermore, the probability of multivesicular release increases if release probability is increased (Tong and Jahr, 1994), as occurs at the synapse that we describe here in the presence of bicuculline. It is interesting to note that multiple vesicular release has also been seen at inhibitory synapses between neurons in the molecular layer of the cerebellum (Auger et al., 1998).

\section{Presynaptic inhibition of GABA release}

Unlike most GABAergic synapses onto Purkinje cells (Saitow et al., 2000; this study), the Lugaro cell synapses are subject to strong presynaptic inhibitory control mediated by $\mathrm{GABA}_{\mathrm{A}}$ receptors. The $\mathrm{GABA}_{\mathrm{A}}$ receptor-mediated inhibition is long lasting so that, in the absence of bicuculline, no release occurs from the input over tens of seconds. Because our modeling data suggest a dwell time of GABA in the synaptic cleft of a few milliseconds, the source of GABA is unlikely to be the input itself. Perhaps the most likely source of background GABA is spillover from the very active basket and stellate cells. The question thus arises of where the $\mathrm{GABA}_{\mathrm{A}}$ receptors are situated. In light of the fact that the current can generally be evoked at many places along the Purkinje cell layer, the stimulus was presumably usually on an axon. When it is also considered that care was taken to ensure that the stimulus threshold was not changed during bicuculline washout, it seems likely that the inhibition occurs distal to the site of action potential generation, rather than being attributable to a change in stimulation efficacy. This suggests that the $\mathrm{GABA}_{\mathrm{A}}$ receptors are either on the distal axon, resulting in intermittent branch point failure or axon block, or on the synaptic terminals. In either case, the receptors would be exposed to GABA spillover from other interneurons. Thus, the Lugaro cell input to Purkinje cells would release transmitter only if the activity of the other interneurons was reduced, allowing background GABA levels to fall (as mimicked by the presence of bicuculline). It is interesting to note that $\mathrm{GABA}_{\mathrm{A}}$ receptors have also been suggested to be present on the axons or terminals of other cell types in the cerebellum (Pouzat and Marty, 1999). Note that under these conditions of higher release probability, if the connection has more than one release site, the resulting currents would be even larger than those seen here from a single release site in the absence of bicuculline (up to $>1 \mathrm{nA}$ ). When this presynaptic modulation is combined with the dependence of release from the Lugaro cell on the presence of serotonin, an interesting model can be proposed.

\section{Conclusion and proposed physiological significance}

We have described a novel synaptic input to Purkinje cells that will only release transmitter when the presynaptic cell is stimulated to fire by the presence of serotonin. We conclude that the only presynaptic source consistent with the behavior of the synaptic currents is the Lugaro cell. This is the first description of this synapse.

We suggest that this synapse is active only when other interneurons impinging onto the Purkinje cell are inhibited. The firing rate of Purkinje cells is strongly controlled by the level of synaptic inhibition received (Häusser and Clark, 1997; De Schutter, 1999; Jaeger and Bower, 1999). Moreover, serotonin itself affects Purkinje cells, rendering them especially susceptible to synaptic inhibition (Williams et al., 2002). Thus, the Lugaro cell input occurring in the absence of other inhibition would be of major functional significance.

The serotonergic input to the cerebellum originates from the raphe nuclei in the brainstem (Kerr and Bishop, 1991). Activation of this pathway and release of serotonin into the cerebellar cortex occur particularly during motor activity (Jacobs and Fornal, 1993; Mendlin et al., 1996; Dieudonné, 2001). The effects of serotonin in the cerebellum are thought to occur primarily via volume transmission rather than at synaptic specializations (Dieudonné, 2001), and any nearby neurons expressing serotonin receptors would be affected. The effect of serotonin on different cerebellar neurons is controversial (Strahlendorf et al., 1989; Mitoma et al., 1994; Mitoma and Konishi, 1999; Dieudonné and Dumoulin, 2000), but during excitation of the network related to motor activity, Lugaro cells would presumably be stimulated. Anatomical data suggest that Lugaro cells form connections onto basket and stellate cells (Lainé and Axelrad, 1998). If these synapses resulted in sufficient inhibition of basket and stellate cells, release at the proposed inputs from Lugaro cells onto Purkinje cells could be favored, resulting in the synchronization of the output of many Purkinje cells. Therefore, during motor 
activity, Lugaro cells may provide the major controlling influence over Purkinje cell activity and thus the output of the cerebellum.

\section{References}

Aoki E, Semba R, Kashiwamata S (1986) New candidates for GABAergic neurons in the rat cerebellum: an immunocytochemical study with antiGABA antibody. Neurosci Lett 68:267-271.

Auger C, Kondo S, Marty A (1998) Multivesicular release at single functional synaptic sites in cerebellar stellate and basket cells. J Neurosci 18:4532-4547.

Bernard C, Axelrad H (1993) Effects of recurrent collateral inhibition on Purkinje cell activity in the immature rat cerebellar cortex: an in vivo electrophysiological study. Brain Res 626:234-258.

Boué-Grabot É, Roudbaraki M, Bascles L, Tramu G, Bloch B, Garret M (1998) Expression of GABA receptor $\rho$ subunits in rat brain. J Neurochem 70:899-907.

Chan-Palay V (1971) The recurrent collaterals of Purkinje cell axons: a correlated study of the rat's cerebellar cortex with electron microscopy and the Golgi method. Z Anat Entwicklungsgesch 134:200-234.

Chebib M, Mewett KN, Johnston GA (1998) GABA $_{C}$ receptor antagonists differentiate between human $\rho 1$ and $\rho 2$ receptors expressed in Xenopus oocytes. Eur J Pharmacol 357:227-234.

Chen JQ, Galanakis D, Ganellin CR, Dunn PM, Jenkinson DH (2000) bisQuinolinium cyclophanes: 8,14-diaza-1,7(1,4)-diquinolinacyclotetradecaphane (UCL 1848), a highly potent and selective, nonpeptidic blocker of the apamin-sensitive $\mathrm{Ca}(2+)$-activated $\mathrm{K}(+)$ channel. J Med Chem 43:3478-3481.

Cherubini E, Conti F (2001) Generating diversity at GABAergic synapses. Trends Neurosci 24:155-162.

Clements JD (1996) Transmitter time course in the synaptic cleft: its role in central synaptic function. Trends Neurosci 19:163-171.

Clements JD, Lester RAJ, Tong G, Jahr CE, Westbrook GL (1992) The time course of glutamate in the synaptic cleft. Science 258:1498-1501.

Colquhoun D, Hawkes AG (1995) The principles of the stochastic interpretation of ion-channel mechanisms. In: Single-channel recordings (Sakmann B, Neher E, eds), pp 397-482. New York: Plenum.

De Schutter E (1999) Using realistic models to study synaptic integration in cerebellar Purkinje cells. Rev Neurosci 10:233-245.

Dieudonné S (2001) Serotonergic neuromodulation in the cerebellar cortex: cellular, synaptic, and molecular basis. The Neuroscientist 7:207-219.

Dieudonné S, Dumoulin A (2000) Serotonin-driven long-range inhibitory connections in the cerebellar cortex. J Neurosci 20:1837-1848.

Dumoulin A, Triller A, Dieudonné S (2001) IPSC kinetics at identified GABAergic and mixed GABAergic and glycinergic synapses onto cerebellar Golgi cells. J Neurosci 21:6045-6057.

Eccles JC, Llinas R, Sasaki K (1966) Intracellularly recorded responses of the cerebellar Purkinje cells. Exp Brain Res 1:161-183.

Edwards FA, Konnerth A, Sakmann B, Takahashi T (1989) A thin slice preparation for patch clamp recordings from neurons of the mammalian central nervous system. Pflügers Arch 41:600-612.

Fenwick EM, Marty A, Neher E (1982) A patch-clamp study of bovine chromaffin cells and of their sensitivity to acetylcholine. J Physiol (Lond) 331:577-597.

Fritschy JM, Benke D, Mertens S, Oertel WH, Bachi T, Mohler H (1992) Five subtypes of type A $\gamma$-aminobutyric acid receptors identified in neurons by double and triple immunofluorescence staining with subunitspecific antibodies. Proc Natl Acad Sci USA 89:6726-6730.

Hamann M, Desarmenien M, Desaulles E, Bader MF, Feltz P (1988) Quantitative evaluation of the properties of a pyridazinyl GABA derivative (SR 95531) as a GABAA competitive antagonist. An electrophysiological approach. Brain Res 442:287-296.

Häusser M, Clark BA (1997) Tonic synaptic inhibition modulates neuronal output pattern and spatiotemporal synaptic integration. Neuron 19:665-678.

Jacobs BL, Fornal CA (1993) 5-HT and motor control: a hypothesis. Trends Neurosci 16:346-352.

Jaeger D, Bower JM (1999) Synaptic control of spiking in cerebellar Purkinje cells: dynamic current clamp based on model conductances. J Neurosci 19:6090-6101.

Jonas P, Bischofberger J, Sandkühler J (1998) Corelease of two fast neurotransmitters at a central synapse. Science 281:419-424.
Jones MV, Westbrook GL (1995) Desensitized states prolong $\mathrm{GABA}_{\mathrm{A}}$ channel responses to brief agonist pulses. Neuron 15:181-191.

Jones MV, Sahara Y, Dzubay JA, Westbrook GL (1998) Defining affinity with the GABA $A_{\triangle}$ receptor. J Neurosci 18:8590-8604.

Jones MV, Jonas P, Sahara Y, Westbrook GL (2001) Microscopic kinetics and energetics distinguish GABA(A) receptor agonists from antagonists. Biophys J 81:2660-2670.

Kerr CW, Bishop GA (1991) Topographical organization in the origin of serotoninergic projections to different regions of the cat cerebellar cortex. J Comp Neurol 304:502-515.

Khawaled R, Bruening-Wright A, Adelman JP, Maylie J (1999) Bicuculline block of small-conductance calcium-activated potassium channels. Pflügers Arch 438:314-321.

Kuhse J, Schmieden V, Betz H (1990) A single amino acid exchange alters the pharmacology of neonatal rat glycine receptor subunit. Neuron 5:867-873.

Lainé J, Axelrad H (1996) Morphology of the Golgi-impregnated Lugaro cell in the rat cerebellar cortex: a reappraisal with a description of its axon. J Comp Neurol 375:618-640.

Lainé J, Axelrad H (1998) Lugaro cells target basket and stellate cells in the cerebellar cortex. NeuroReport 9:2399-2403.

Lainé J, Axelrad H, Rahbi N (1992) Intermediate cells of Lugaro are present in the immature rat cerebellar cortex at an earlier stage than previously thought. Neurosci Lett 145:225-228.

Laurie DJ, Seeburg PH, Wisden W (1992) The distribution of $13 \mathrm{GABA}_{\mathrm{A}}$ receptor subunit mRNAs in the rat brain. II. Olfactory bulb and cerebellum. J Neurosci 12:1063-1076.

Llano I, Marty A, Armstrong CM, Konnerth A (1991) Synaptic- and agonist-induced excitatory currents of Purkinje cells in rat cerebellar slices. J Physiol (Lond) 434:183-213.

Lüddens H, Korpi ER (1995) GABA antagonists differentiate between recombinant $\mathrm{GABA}_{\mathrm{A}} /$ benzodiazepine receptor subtypes. J Neurosci 15:6957-6962.

Maconochie DJ, Zempel JM, Steinbach JH (1994) How quickly can GABA receptors open? Neuron 12:61-71.

Mendlin A, Martin FJ, Rueter LE, Jacobs BL (1996) Neuronal release of serotonin in the cerebellum of behaving rats: an in vivo microdialysis study. J Neurochem 67:617-622.

Mitoma H, Konishi S (1999) Monoaminergic long-term facilitation of GABA-mediated inhibitory transmission at cerebellar synapses. Neuroscience 88:871-883.

Mitoma H, Kobayashi T, Song S-Y, Konishi S (1994) Enhancement by serotonin of GABA-mediated inhibitory synaptic currents in rat cerebellar Purkinje cells. Neurosci Lett 173:127-130.

Mozrzymas JW, Barberis A, Michalak K, Cherubini E (1999) Chlorpromazine inhibits miniature GABAergic currents by reducing the binding and by increasing the unbinding rate of $\mathrm{GABA}_{\mathrm{A}}$ receptors. J Neurosci 19:2474-2488

Pouzat C, Hestrin S (1997) Developmental regulation of basket/stellate cell $\rightarrow$ Purkinje cell synapses in the cerebellum. J Neurosci 17:9104-9112.

Pouzat C, Marty A (1999) Somatic recording of GABAergic autoreceptor current in cerebellar stellate and basket cells. J Neurosci 19:1675-1690.

Ragozzino D, Woodward RM, Murata Y, Eusebi F, Overman LE, Miledi R (1996) Design and in vitro pharmacology of a selective gammaaminobutyric acid $_{C}$ receptor antagonist. Mol Pharmacol 50:1024-1030.

Rozzo A, Armellin M, Franzot J, Chiaruttini C, Nistri A, Tongiorgi E (2002) Expression and dendritic mRNA localization of $\mathrm{GABA}_{\mathrm{C}}$ receptor rhol and rho2 subunits in developing rat brain and spinal cord. Eur J Neurosci 15:1747-1758.

Sahin M, Hockfield S (1990) Molecular identification of the Lugaro cell in the cat cerebellar cortex. J Comp Neurol 301:575-584.

Saitow F, Satake S, Yamada J, Konishi S (2000) $\beta$-Adrenergic receptormediated presynaptic facilitation of inhibitory GABAergic transmission at cerebellar interneuron-Purkinje cell synapses. J Neurophysiol 84:2016-2025.

Schneggenburger R, Konnerth A (1992) GABA-mediated synaptic transmission in neuroendocrine cells: a patch-clamp study in a pituitary slice preparation. Pflügers Arch 421:364-373.

Seutin V, Johnson SW (1999) Recent advances in the pharmacology of quaternary salts of bicuculline. Trends Pharmacol Sci 20:268-270.

Seutin V, Scuvee-Moreau J, Dresse A (1997) Evidence for a non-GABAergic 
action of quaternary salts of bicuculline on dopaminergic neurons. Neuropharmacology 36:1653-1657.

Shah M, Haylett DG (2000) The pharmacology of hSK1 Ca2+-activated $\mathrm{K}+$ channels expressed in mammalian cell lines. $\mathrm{Br} \mathrm{J}$ Pharmacol 129:627-630.

Shimada S, Cutting G, Uhl GR (1992) $\gamma$-Aminobutyric acid A or C receptor? $\gamma$-Aminobutyric acid $\rho 1$ receptor RNA induces bicuculline-, barbiturate-, and benzodiazepine-insensitive $\gamma$-aminobutyric acid responses in Xenopus oocytes. Mol Pharmacol 41:683-687.

Shingai R, Yanagi K, Fukushima T, Sakata K, Ogurusu T (1996) Functional expression of GABA $\rho 3$ receptors in Xenopus oocytes. Neurosci Res 26:387-390.

Strahlendorf JC, Lee M, Strahlendorf HK (1989) Modulatory role of serotonin on GABA-elicited inhibition of cerebellar Purkinje cells. Neuroscience 30:117-125.

Strøbæk D, Jorgensen TD, Christophersen P, Ahring PK, Olesen SP (2000) Pharmacological characterization of small-conductance $\mathrm{Ca}^{2+}$-activated $\mathrm{K}^{+}$channels stably expressed in HEK 293 cells. Br J Pharmacol 129:991-999.

Than M, Szabo B (2002) Analysis of the function of $\mathrm{GABA}_{\mathrm{B}}$ receptors on inhibitory afferent neurons of Purkinje cells in the cerebellar cortex of the rat. Eur J Neurosci 15:1575-1584.

Tong G, Jahr CE (1994) Multivesicular release from excitatory synapses of cultured hippocampal neurons. Neuron 12:51-59.

Ueno S, Bracamontes J, Zorumski C, Weiss DS, Steinbach JH (1997) Bicuculline and gabazine are allosteric inhibitors of channel opening of the $\mathrm{GABA}_{\mathrm{A}}$ receptor. J Neurosci 17:625-634.

Vincent P, Marty A (1996) Fluctuations of inhibitory postsynaptic currents in Purkinje cells from rat cerebellar slices. J Physiol (Lond) 494:183-199.

Wadiche JI, Jahr CE (2001) Multivesicular release at climbing fiberPurkinje cell synapses. Neuron 32:301-313.

Wang TL, Guggino WB, Cutting GR (1994) A novel $\gamma$-aminobutyric acid receptor subunit $\left(\rho_{2}\right)$ cloned from human retina forms bicucullineinsensitive homooligomeric receptors in Xenopus oocytes. J Neurosci 14:6524-6531.

Williams SR, Christensen SR, Stuart GJ, Häusser M (2002) Membrane potential bistability is controlled by the hyperpolarization-activated current $\mathrm{I}_{\mathrm{H}}$ in rat cerebellar Purkinje neurons in vitro. J Physiol (Lond) 539:469-483. 